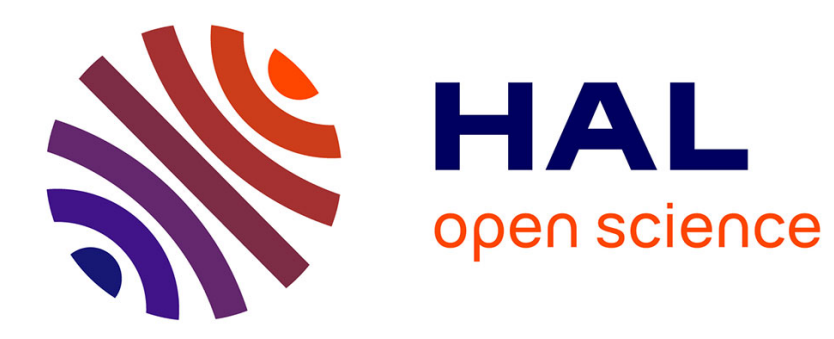

\title{
The Paris Agreement, EU Climate Law and the Energy Union
}

Estelle Brosset, Sandrine Maljean-Dubois

\section{To cite this version:}

Estelle Brosset, Sandrine Maljean-Dubois. The Paris Agreement, EU Climate Law and the Energy

Union. Research Handbook on EU Environmental Law, 2020. halshs-02920660

\section{HAL Id: halshs-02920660 \\ https://shs.hal.science/halshs-02920660}

Submitted on 24 Aug 2020

HAL is a multi-disciplinary open access archive for the deposit and dissemination of scientific research documents, whether they are published or not. The documents may come from teaching and research institutions in France or abroad, or from public or private research centers.
L'archive ouverte pluridisciplinaire HAL, est destinée au dépôt et à la diffusion de documents scientifiques de niveau recherche, publiés ou non, émanant des établissements d'enseignement et de recherche français ou étrangers, des laboratoires publics ou privés. 
Paru in Research Handbook on EU Environmental Law, dir. Mariolina Eliantonio et Marjan Peeters, Edward Elgar, 2020, pp. 412-427.

\title{
The Paris Agreement, EU Climate Law and the Energy Union
}

\author{
Estelle Brosset
}

Sandrine Maljean-Dubois

\begin{abstract}
The European Union has gradually developed a comprehensive body of legislation aimed at protecting the environment, consolidating its competences in this field in successive stages. Within this framework, climate change has been given a high priority and is one of the most prominent areas of the EU's external and internal policy. In a fruitful interplay, the EU has driven the evolution of the international regime and tried to influence international negotiations. In turn, the international regime has urged the Union to establish common objectives and means to tackle climate change in order to implement its international commitments. EU legislation and the international climate regime have been in constant interaction, and have evolved together. Their interactions played a major role in the shaping of the EU climate policy facing conflicting challenges of ambition, acceptability and effectiveness.
\end{abstract}




\section{Introduction}

The European Union has gradually developed a comprehensive body of legislation aimed at protecting the environment, consolidating its competences in this field in successive stages. Within this framework, climate change has been given a high priority and is one of the most prominent areas of the EU's external and internal policy.

From the precursory European Economic Community (Treaty of Rome, 1957) to the European Union (Treaty on European Union, Maastricht, 1992), the EU has progressively developed a prevention-oriented and comprehensive environmental policy in which climate change received particular attention since the 1990s. The Lisbon Treaty (2008) acknowledged this specificity, stating that, in addition to its internal environmental objectives, the Union is aimed at "promoting measures at international level to deal with regional or worldwide environmental problems, and in particular combating climate change" (Art. 191 (1) TFEU). The Lisbon Treaty is also significant as it confers upon the EU a shared competence in the energy sector for the pursuit of objectives defined in the new 194 (1) TFEU, including the objective to "c) promote energy efficiency and energy saving and the development of new and renewable forms of energy".

The EU has played a significant role in the development of the international legal regime for climate change. After setting out the approach from the Paris Agreement and its implications for the EU (2), this chapter will show that international interactions played a major role in the shaping of the external (3) and internal (4) climate EU policy. Section 5 concludes.

\section{The new approach of the Paris Agreement and its implications for the EU}

\subsection{The Paris Agreement}

The international climate regime was built in parallel and also in stages. Its foundation was laid with the creation of the Intergovernmental Panel on Climate Change (IPCC) in 1988. States then developed a specific international legal regime, based on the United Nations Framework Convention on Climate Change (UNFCCC, 1992). In 1997, the Kyoto Protocol set out obligations for the reduction of greenhouse gas emissions for the period 2008-2012 relative to 1990 levels. Negotiations on the post-2012 regime, and later on the post-2020 regime, were slow and arduous. As scientific papers and IPCC reports came out, a very strong consensus emerged as to the need to take action. States thus found themselves caught up in a paradox: on the one hand, increasing shared awareness of the risks and willingness to act in order to contain those risks, and on the other hand, a negotiation process at a standstill. The Copenhagen Accord, the substance of which was then repeated in the decisions of the Conference of the Parties in Cancun, governs the current period up until 2020. The Paris Agreement, a new treaty adopted in 2015, lays down the framework with regard to the reduction of emissions starting from 2020. The treaty was signed by a large number of countries and quickly ratified. It came into force within a year, despite the very strict conditions set therefor; there are 185 Parties (02/14/2019).

The Paris Agreement is very different from its "predecessor", the Kyoto Protocol. The compromise reached in Paris illustrates a certain evolution of the way States commit themselves. In terms of substance, it represents a subtle combination of bottom-up and topdown approaches. 


\section{$1^{\circ} \mathrm{A}$ bottom-up approach}

Under the Paris Agreement, the Parties themselves establish their contribution's level of ambition, at a national level, keeping in mind the collective objective of holding global warming well below under $2^{\circ} \mathrm{C}$, and pursuing efforts to limit the temperature increase to $1.5^{\circ} \mathrm{C} .{ }^{1}$ National contributions should ultimately follow synchronised time frames based on 5year cycles. The collective effort is therefore the result of the aggregation of "nationally determined" contributions. At the global level, there has been no burden-sharing of the implementation of this collective objective, as it had been the case pursuant to the Kyoto Protocol. ${ }^{2}$ However, Regional Economic Integration Organisations (REIO) and their member States have the possibility to act jointly and send a common "nationally determined" contribution. In that case, they shall notify the secretariat of the terms of their agreement, which shall in turn inform the Parties and signatories to the Convention of the terms of that agreement (Article 4 (16)).

As contributions are nationally determined, the question arises as to whether the Agreement retains its raison d'être. The answer is yes, for two reasons. The first raison d'être of the treaty is to create momentum by encouraging States first to commit, and then to gradually increase their level of commitment. The second raison d'être is to guarantee the transparency of actions and policies.

\section{$2^{\circ}$ Raising the level of ambition}

Each national determined contribution must constitute a progress from the previous contribution. ${ }^{3}$ However, the Parties are free under the Paris Agreement to determine this progression, which may lie in the form and/or substance of their contributions. Alongside the obligation to submit a contribution at its highest possible ambition, which must be more ambitious than the previous one, Parties may "at any time" amend their contribution "with a view to enhancing its level of ambition". ${ }^{4}$ In order both to assess the adequacy of the efforts aggregated altogether as against the desired global trajectory according to the Paris Agreement, and to increase the pressure on States, Article 14 lays down the principle of a global review, referred to as a "global stocktake", that will take place every five years.

\section{$3^{\circ}$ Ensuring transparency and building confidence}

The provisions ensuring transparency and control are particularly important in a flexible system based on contributions nationally determined by States. These provisions reintroduce more or less top-down aspects into an approach that is mostly bottom-up, and they are given a major role to play: establishing trust between States (thereby leading them to increase their commitment) and enabling the monitoring of the Parties' efforts, in order to confront them with the target emissions trajectory. Negotiators were well aware of this and special care was dedicated to this matter on which a great part of the robustness of the Paris Agreement

\footnotetext{
${ }^{1}$ S. Dröge, O. Geden, 'After the Paris Agreement New Challenges for the EU's Leadership in Climate Policy', Stiftung Wissenschaft und Politik German Institute for International and Security Affairs, SWP Comments (April 2016), 1.

${ }^{2}$ See above.

${ }^{3}$ Art. 3, Decision 1/CP.20 (2014), Lima call for climate action, $\$ 10$

${ }^{4}$ Art. $4 \S 11$.
} 
depended. ${ }^{5}$ The transparency framework ${ }^{6}$ and compliance mechanism ${ }^{7}$ have been further detailed in the rulebook of the Paris Agreement, adopted in Katowice at the COP $24 .{ }^{8}$

\subsection{Implications for the European Union}

Regarding the challenge of implementing the Paris Agreement, which extends largely beyond mitigation to adaptation and finance, "the EU may be under particular scrutiny because it has long been a 'leader' in international climate politics, including through the pursuit of ambitious domestic policies". ${ }^{9}$ However, the EU faces growing difficulties in completing its internal decision-making. In the wider EU of 28 countries, effective decisions on climate and energy issues are much harder to adopt.

$1^{\circ}$ The ratification step and the first EU "nationally determined contribution"

Among only a few other parties to the UNFCCC, the EU had communicated its "intended nationally determined contributions", as requested, "by the first quarter of 2015 by those Parties ready to do so". ${ }^{10}$ Following the view of the European Council expressed in October $2014^{11}$, the EU Environment Council meeting communicated in March 2015 its objective of reducing greenhouse gas emissions by at least 40 percent below 1990 levels by 2030 as the EU's official contribution to the ongoing climate talks under the UNFCCC in order to prepare for the Paris Agreement negotiations. ${ }^{12}$ The EU's target was presented as unconditional, regardless of the outcome of the COP 21

Ratifications of the Paris Agreement took place at a steady pace, raising fear that the Paris Agreement "may enter into force before the EU and its member states would be able to become parties, which would limit their role in follow-up decision-making". ${ }^{13}$ However, after having signed the Paris Agreement during a formal ceremony in New York on 22 April 2016, the EU approved it on 5 October 2016, just before the COP $22^{14}$. According to its Article 20 (2), as a REIO, the EU "shall be bound by all the obligations under this Agreement". Because they are together Parties to the Agreement, the EU and its Member States shall decide on their respective responsibilities for the performance of their obligations under this Agreement. Article 20 (3) asks REIOs to clarify the allocation of competences between the organisation and its Member States. In fact, the EU's declaration offers little indication from this point of view. ${ }^{15}$

$2^{\circ}$ The raising of the level of ambition of the first national contributions

Since 2015, in this tense context, the EU endeavours to prepare the implementation of the Paris Agreement from 2020 onwards. To limit conflicts, the Commission has progressed cautiously in the development of instruments implementing its international commitment.

\footnotetext{
${ }^{5}$ C. Voigt, 'The Compliance and Implementation Mechanism of the Paris Agreement', RECIEL (2016) 25 (2), $161-173$.

${ }^{6}$ Art. 13 .

${ }^{7}$ Art. 15

${ }^{8}$ See the COP 24/CMA 1 decisions on Modalities, procedures and guidelines for the transparency framework for action and support referred to in Article 13 of the Paris Agreement and Modalities and procedures for the effective operation of the committee to facilitate implementation and promote compliance referred to in Article 15, paragraph 2, of the Paris Agreement (16 December 2018).

${ }^{9}$ S. Oberthür, 'Perspectives on EU Implementation of the Paris Outcome', Carbon \& Climate Law Review (2016) $1,34$.

${ }^{10}$ UNFCCC, Decision 1/CP.20, Lima call for climate action (2014).

${ }^{11}$ Conclusions of the European Council of 23-24 October 2014.

12 Outcome of the Council Meeting, 3373rd Council meeting, Environment Brussels, 6 March 2015.

13 Oberthür (2016) CCLR, 34-45.

${ }^{14}$ Council Decision (EU) 2016/1841 of 5 October 2016 on the conclusion, on behalf of the European Union, of the Paris Agreement adopted under the United Nations Framework Convention on Climate Change, OJ L 282, 19.10.2016, 1-3.

${ }^{15}$ Declaration by the Union made in accordance with Article 20(3) of the Paris Agreement, OJ L 282, 19.10.2016, 4.
} 
Thus, it postponed the adoption of a detailed regulation for the accounting of land use, landuse changes, and forestry (LULUCF). This very important legislation for Member States with a strong agricultural sector was finally adopted in 2018. ${ }^{16}$ Similarly, the Commission had some trouble achieving the adoption of its "Roadmap for Moving to a Competitive Low Carbon Economy in 2050" put forward in $2011^{17}$ but rejected by the Council because of Poland's opposition. On 28 November 2018, the Commission presented its strategic longterm vision, calling for a "both climate neutral and prosperous" Europe by $2050 .{ }^{18}$ The Commission hopes that the EU will be able to submit its strategy to the UNFCCC by early 2020, as requested under the Paris Agreement Article 4 (19).

\section{$3^{\circ}$ Implementation and compliance mechanisms}

From an implementation and compliance point of view, an interesting feature is the coexistence of an international regime - a mixed agreement to which both the EU and its Member States are parties - and a regional regime within the framework of the European Union. In both regimes, one of the key challenges remains to ensure the effective application of the law, which requires the setting-up of compliance control mechanisms. However, under the Paris Agreement, states' obligations are mainly procedural and the compliance mechanism adopted during COP24 takes a managerial approach. ${ }^{19}$ The monitoring of its implementation by Member States with ultimate supervision of the ECJwill be all the more complementary and necessary.

Furthermore, the implementation of the Paris Agreement still raises interesting questions regarding the sharing of competences and responsibilities between the EU and its Member States, as illustrated by the Dutch climate litigation case "Urgenda" ${ }^{20}$ The Dutch court did "not assess the legality of the EU overall greenhouse gas reduction target of $20 \%$ ", nor did it assess "the legality of the Effort Sharing Decision target for the Netherlands, which is set at a $16 \%$ greenhouse gas emission reduction compared to 2005 levels. However, since the Dutch court ruled that the EU overall target is insufficient, this implies a negative assessment on the lawfulness of the core aim of EU climate law". ${ }^{21}$

\section{3) The EU as a global actor for climate?}

The EU now has a long-standing practice and a growing role on the international environmental scene, as well illustrated in the field of climate change. Yet, as the only regional organisation member of the UNFCCC, the Kyoto Protocol and the Paris Agreement, the EU can be seen as a sui generis international climate actor ${ }^{22}$. More than that, since the early 1990s, the EU has had high aspirations to leadership and has been widely viewed as a global leader among academics ${ }^{23}$. The EU has tried to "make a virtue of its relative lack of

\footnotetext{
${ }^{16}$ Aforementioned Regulation (EU) 2018/841.

${ }^{17}$ Communication from the Commission to the European Parliament, the Council, the European Economic and Social Committee and the Committee of the Regions, A Roadmap for moving to a competitive low carbon economy in 2050, COM/2011/0112 final.

${ }^{18}$ Communication from the Commission to the European Parliament, the European Council, the Council, the European Economic and Social Committee, the Committee of the Regions and the European Investment Bank, A Clean Planet for all. A European strategic long-term vision for a prosperous, modern, competitive and climate neutral economy, Brussels, 28.11.2018 COM (2018) 773 final.

${ }^{19}$ See above.

${ }^{20}$ Urgenda Foundation and 886 Individuals v. The State of the Netherlands, Gerechtshof Den Haag, 200.178.245/01, ECLI:NL:RBDHA:2015:7196,09-10-2018.

${ }^{21}$ M. Peeters, 'Case Note Urgenda Foundation and 886 Individuals v. The State of the Netherlands: The Dilemma of More Ambitious Greenhouse Gas Reduction Action by EU Member States', RECIEL 25 (1) (2016) 125.

${ }^{22}$ Using the concept of 'actorship' to describe the ability to exert influence on the external world according to J.-U. Wunderlich, 'The EU an Actor Sui Generis? A Comparison of EU and ASEAN Actorness', Journal of common market studies (50)4, 653-669. See Carolina B. Pavese, Diarmuid Torney, 'The contribution of the European Union on global climate change governance: explaining the conditions for EU actorness', Revista Brasileira de Politica Internacional (2012), 55, 125.

${ }^{23}$ S. Afionis, 'The European Union as a negotiator in the international climate change regime', Int Environ Agreements (2011) 11:341-360.
} 
'hard power' by relying heavily on 'soft power"" 24 or "normative power". ${ }^{25}$ But its influence within and outside the Paris regime has varied, which raises the question: is it well-equipped to conduct its ambitious climate external policy?

\subsection{A shifting influence on the international climate regime}

For many years, the EU pursued the strategy of "leading by example" in international climate negotiations. During and after the Copenhagen Conference, given a new international context, its perceived leadership dropped significantly, the EU recalibrated its leadership role to win it back - at least partially, being "more realistic and skilful in strategically combining its resource-based leadership with its instrumental leadership". ${ }^{26}$ As noted by Oberthür, "it invested in building a broad coalition of ambitious parties across the North-South divide and built bridges with and between other actors: it became a 'leadiator' (i.e., a leader and mediator)" ${ }^{27}$ Due to its new "leadiator" role, the EU was quite successful in influencing the negotiations in Paris and shaping their outcome. However, "at the time of the Paris conference, the EU was a middle power in international climate politics in an international constellation characterized by a trend toward multi-polarity, but with two heavyweights: the US and China". ${ }^{28}$ Pushing for a relatively ambitious outcome regarding mitigation, it has been taking more defensive stances on climate finance and ambition. ${ }^{29}$ In a more "fragmented leadership landscape" 30 , the weakening of EU's influence has been confirmed by the next COPs, the EU having disappointed many of its partners "as it did not deliver as a constructive negotiator and bridge builder". ${ }^{31}$ At the COP24 in Katowice, Poland, the international context was morose in particular due to the announced withdrawal of the US from the Paris Agreement and potentially of Brazil too. There was much expectation from the EU for instance on the raising of ambition or on finance but, because of its internal disunity, it was unable to be anything more than a bystander. ${ }^{32}$

\subsection{The EU external climate policy outside the international climate regime}

Beyond the UNFCCC, the EU has increasingly sought to use its political and economic influence and advance climate change objectives through its bilateral and interregional external relations. ${ }^{33}$ In particular, the EU, as the world's largest provider of development assistance, has, at least in quantitative terms, the potential to support climate action. ${ }^{34}$ Climate funding from the EU and its Member States amounted to 20.4 billion in 2017. ${ }^{35}$ In the near future, it could invest in intensifying partnerships with key countries and other actors

We agree that political leadership is "a complex phenomenon, ill-defined, poorly understood, and subject to recurrent controversy". See O. Young, O. 'Political Leadership and Regime Formation: On the Development of Institutions in International Society' International Organization (1991) 45(3), 281-308.

${ }^{24}$ R. K. W. Wurzel, J. Connelly, 'European Union political leadership in international climate change politics', In R. K. W. Wurzel \& J. Connelly (Eds.), The European Union as a leader in international climate change politics (Routledge, 2010$) 14$.

${ }_{25}$ T. Christiansen, 'The European Union and global governance', in Anna Triandafyllidou (ed.), Global governance from regional perspectives: a critical view (OUP, 2017).

${ }^{26} \mathrm{Ch}$. Parker, C. Karlsson 'The European Union as a global climate leader: confronting aspiration with evidence', Int Environ Agreements (2017) 17(4) 468.

${ }^{27}$ S. Oberthür, 'The European Union and the Paris Agreement: leader, mediator, or bystander?', Climate change (2016) (8)1 445.

${ }^{28}$ Oberthür (2016) Climate change, 445.

${ }^{29}$ Oberthür (2016) Climate change, 445.

${ }^{30}$ C. Parker, C. Karlsson, M. Hjerpe, 'Climate change leaders and followers: Leadership recognition and selection in the UNFCCC negotiations', International Relations (2015) 29(4), 434-454.

${ }^{31}$ S. Droge, 'International climate policy leadership after COP23: the EU must resume its leading role, but cannot do so alone' in Nicolai von Ondarza, Stiftung Wissenschaft und Politik, German Institute for International and Security Affairs (2018) 1-7.

${ }^{32}$ To use the Oberthür's categories. Oberthür (2016) Climate change, 445.

${ }^{33} \mathrm{~K}$. Kulovesi, 'Climate change in EU external relations: please follow my example (or I might force you to)', in The external environmental policy of the European Union: EU and international law perspectives (2012) 9,139.

${ }^{34}$ See for instance the founding text of the European Commission, Using Innovative and Effective Approaches to Deliver Climate Change Support to Developing Countries, 2011.

${ }^{35}$ See https://ec.europa.eu/clima/sites/clima/files/docs/climate_finance_leaflet_en.pdf 
supporting the model of the Paris Agreement. ${ }^{36}$ Some stand for the rise of minilateralism ${ }^{37}$, of multiple bilateralism, involving the EU, China, India and other key emitters considering that it "holds the potential to develop into a networked form of co-leadership" 38 , or even of trilateralism between the EU, China and African countries, to pursue "joint approaches" to "speed up the implementation of the Paris Agreement wherever possible, including the implementation of Nationally Determined Contributions". 39

\subsection{Is the EU well-equipped to pursue an ambitious external climate policy?}

The climate change field illustrates the fact that the EU has a "range of political resources and diplomatic capabilities that is unique among any other actor in international affairs". ${ }^{40} \mathrm{~A}$ specific feature in climate change negotiations is that the EU uses since 2004 a system of "lead negotiators" 41 and "issue leaders" 42 acting under the formal authority of the Presidency. ${ }^{43}$ This allows negotiations on behalf of the EU to take place over a longer period than the six-monthly rotating European Presidency. This also allows the Presidency to share the burden of the negotiation task, since climate change negotiations are often too complex to be appropriately handled by a single Presidency.

But the Union (more precisely the Commission and the Commission jointly with Member States) remains torn between its aspiration to an international leadership, and the hurdles to become a global actor. Because of its internal contradictions, the EU is not always able to perform, beyond its Member States, as a powerful negotiator, even if the EU and its Member States are bound by the principle of loyal cooperation ${ }^{44}$. From this point of view, the EU policy "has purposefully given rise to (too) high expectations, without having either the resources or the political will among national governments to actually be able to deliver on these expectations". ${ }^{45}$

\section{4) The EU's internal climate policy}

In order to understand the EU's internal climate policy, its foundations as well as its main objectives must be examined.

\subsection{Foundations: climate instruments and the nature of regulation}

\section{$1^{\circ}$ - Overview of the "climate" instruments of the EU}

The first instruments date back to the adoption of the United Nations Framework Convention. Indeed, one of the first acts adopted on this issue was decision 93/389/EEC of the Council of 24 June 1993, for a monitoring mechanism of Community $\mathrm{CO}_{2}$ and other greenhouse gas

\footnotetext{
${ }^{36}$ S. Droge (2018) 1-7.

${ }^{37}$ M. Naim, 'Minilateralism; the Magic Number to Get Real International Action', Foreign Policy (2009); R. Eckersley, 'Moving Forward in the Climate Negotiations: Multilateralism or Minilateralism?', Global Environmental Politics (2012) 12:2, 24-40.

${ }^{38}$ D. Belis, S. Schunz, Simon, T. Wang, D. Jayaram, 'Climate Diplomacy and the Rise of 'Multiple Bilateralism' between China, India and the EU', Carbon \& climate law review (2018)12(2), 85-97.

${ }^{39}$ M. Weigel, A. Demissie, 'A new climate trilateralism? Opportunities for cooperation between the EU, China and African countries on addressing climate change', Deutsches Institut für Entwicklungspolitik, Bonn (2017).

${ }^{40}$ S. Droge (2018) 1-7.

${ }^{41}$ These "lead negotiators" represent the European Union and their main role is to conduct negotiations on a day-to-day basis in the various formations.

${ }^{42}$ The "issue leaders" do not represent the EU but support the work of lead negotiators on specific issues of the negotiations.

${ }^{43}$ T. Delreux, K. Van den Brande, 'Taking the lead: informal division of labour in the EU's external environmental policy-making', Journal of European Public Policy (2013) $20: 1,113-131$.

${ }^{44}$ Article 4 (3) TEU.

${ }^{45}$ T. Christiansen (2017) 211.
} 
emissions ${ }^{46}$, which clearly related ${ }^{47}$ to the commitment of the European Community at the international level. On the same day, the $5^{\text {th }}$ EC Environmental action programme acknowledged the fight against climate change as a key issue of European policy and set out the actions necessary to reach the objective of stabilising GHG emissions at the 1990 level laid down in the Framework Convention. ${ }^{48}$ The adoption of the first European Climate Change Program (ECCP) ${ }^{49}$ in 1999 is traditionally seen as marking the beginning of the Community's internal policy on climate, although here as well the objective was to create a framework for the adoption of measures necessary to meet the Kyoto requirements. Following the discussions led pursuant to the ECCP, the European Parliament and Council adopted directive 2003/87/EC, establishing the Scheme for Greenhouse Gas Emissions Allowance Trading (ETS $)^{50}$, which was clearly the first step in a long and rich list of instruments adopted since then.

These pieces of legislation fit into two main categories. The first one includes instruments incorporating international agreements within EU law, mainly those approving the conclusion of the United Nations Framework Convention on Climate change, of its Kyoto Protocol, and later of the Paris Agreement ${ }^{51}$, as well as those implementing these international undertakings. ${ }^{52}$ It is worth remembering that, when the EU enters into an agreement, its provisions form an integral part of the legal order of the European Union as from its entry into force, even if the internal effects may ultimately be limited. ${ }^{53}$ The second category includes instruments that have shaped European policy, designed to pursue objectives assumed at the international level or for the purpose of building a European climate policy, or both in an intertwined manner. The adoption of the energy-climate package in 2009 , which comprises three directives and one decision ${ }^{54}$, was certainly a key moment. A large part of these instruments was recently revised. ${ }^{55}$ Furthermore, these various pieces of legislation are

\footnotetext{
46 93/389/EEC: Council Decision of 24 June 1993 for a monitoring mechanism of Community CO2 and other greenhouse gas emissions, OJ L 167, 9.7.1993, p. 31-33.

47 "Whereas all Member States and the Community are signatories to the United Nations framework convention on climate change, which, when ratified, will commit the developed countries (...) to take measures to limit anthropogenic emissions of CO2 (...) with the aim of returning individually or jointly to the 1990 levels these anthropogenic emissions by the end of the present decade: whereas, in this perspective, it is desirable to ensure consistency with the monitoring mechanism to be established under the Convention".

${ }^{48}$ Recital 5, Resolution of the Council and the Representatives of the Governments of the Member States, meeting within the Council of 1 February 1993 on a Community programme of policy and action in relation to the environment and sustainable development - A European Community programme of policy and action in relation to the environment and sustainable development, OJ C 138, 17.5.1993, 1-4.

${ }^{49}$ Communication from the Commission to the Council and the European Parliament, Preparing for implementation of the Kyoto Protocol, COM/99/0230 final. Communication from the Commission to the Council and the European Parliament on EU policies and measures to reduce greenhouse gas emissions: towards a European Climate Change Programme (ECCP) COM/2000/0088 final.

${ }^{50}$ Directive 2003/87/EC of the European Parliament and of the Council of 13 October 2003 establishing a scheme for greenhouse gas emission allowance trading within the Community and amending Council Directive 96/61/EC, OJ L 275, 25.10.2003, 32-46.

${ }^{51}$ 94/69/EC: Council Decision of 15 December 1993 concerning the conclusion of the United Nations Framework Convention on Climate Change, OJ L 33, 7.2.1994, 11-12; 2002/358/EC: Council Decision of 25 April 2002 concerning the approval, on behalf of the European Community, of the Kyoto Protocol to the United Nations Framework Convention on Climate Change and the joint fulfilment of commitments thereunder, OJ L 130, 15.5.2002, 1-3; aforementioned Council Decision (EU) 2016/1841, 1-3.

${ }^{52}$ Decision No 280/2004/EC of the European Parliament and of the Council of 11 February 2004 concerning a mechanism for monitoring Community greenhouse gas emissions and for implementing the Kyoto Protocol, OJ L 49, 19.2.2004, 1-8; Regulation (EU) No 525/2013 of the European Parliament and of the Council of 21 May 2013 on a mechanism for monitoring and reporting greenhouse gas emissions and for reporting other information at national and Union level relevant to climate change and repealing Decision No 280/2004/EC, $O J L 165$, 18.6.2013, 13-40.

${ }^{53}$ Judgment of the Court (Grand Chamber) of 21 December 2011, Air Transport Association of America and Others $v$ Secretary of State for Energy and Climate Change, Case C-366/10, Reports of Cases 2011 I-13755: "Consequently, the Kyoto Protocol cannot be relied upon in the context of the present reference for a preliminary ruling for the purpose of assessing the validity of Directive 2008/101" (pt. 78).

${ }^{54}$ Directive 2009/28/EC of the European Parliament and of the Council of 23 April 2009 on the promotion of the use of energy from renewable sources and amending and subsequently repealing Directives 2001/77/EC and 2003/30/EC, OJ L 140, 5.6.2009, 16-62; Directive 2009/29/EC of the European Parliament and of the Council of 23 April 2009 amending Directive 2003/87/EC so as to improve and extend the greenhouse gas emission allowance trading scheme of the Community, OJ L 140, 5.6.2009, 63-87; Directive 2009/31/EC of the European Parliament and of the Council of 23 April 2009 on the geological storage of carbon dioxide and amending Council Directive 85/337/EEC, European Parliament and Council Directives 2000/60/EC, 2001/80/EC, 2004/35/EC, 2006/12/EC, 2008/1/EC and Regulation (EC) No 1013/2006, OJ L 140, 5.6.2009, 114-135; aforementioned Decision No 406/2009/EC, 136-148.

${ }^{55}$ In particular, the ETS directive was revised by Directive (EU) 2018/410 of the European Parliament and of the Council of 14 March 2018 amending Directive 2003/87/EC to enhance cost-effective emission reductions and low-carbon investments and Decision (EU) 2015/1814, $O J$ L 76, 19.3.2018, 3-27. See also aforementioned Regulation (EU) 2018/842, 26-42, which thus extends decision $\mathrm{n}^{\circ} 406 / 2009$. See also Directive (EU) 2018/2001 of the European Parliament and of the Council of 11 December 2018 on the promotion of the use of energy from
} 
supplemented by a range of implementing acts. ${ }^{56}$ These two categories are completed by a third one, which includes all instruments that, without systematically laying down specific obligations, have incorporated the fight against climate change as a general objective, for instance (but not limited to) in the sector of trans-European transport networks ${ }^{57}$, civil protection $^{58}$, protection of the marine environment ${ }^{59}$ or energy efficiency ${ }^{60}$.

The complexity of the regulatory framework is obvious. For example, many sectoral Union acts in the energy and climate field set planning and reporting requirements at the national level, but those requirements have been introduced at different times and in different fields, leading to overlaps and cost-inefficiency. That's why Regulation (EU) 2018/1999 on the Governance of the Energy Union and Climate Action seeks to contribute to greater regulatory certainty by amending twelve legislative acts and by integrating their planning, reporting and monitoring obligations into the integrated national energy and climate plans. ${ }^{61}$

\section{$2^{\circ}$ - The new governance approach}

In terms of form, EU instruments on climate change do not, at first glance, seem very unusual: they include directives, a number of regulations, and decisions addressed to Member States and their economic sectors that lay down obligations in order to achieve a harmonised objective.

However, among those, some feature a more original content, such as the lead directive on the EU ETS. Indeed, the fight against climate change has enabled EU law to test the market as a regulation tool. The chosen option is referred to as "cap and trade". An overall emission "cap" is established for a given period ${ }^{62}$ together with a number of corresponding emissions rights (or allowances). ${ }^{63}$ These allowances are allocated (gratuitously at first, then through an auction process) to polluting facilities targeted by the directive ${ }^{64}$, that can then "trade" them according to their needs. This market-based approach should, in theory, have led to an

renewable sources, OJ L 328, 21.12.2018, p. 82-20: Recital 1: "Directive 2009/28/EC of the European Parliament and of the Council has been substantially amended several times. Since further amendments are to be made, that Directive should be recast in the interests of clarity".

${ }^{56}$ Especially under the ETS directive, for example in order to determine the quantity of allowances to be issued: $2010 / 634 / \mathrm{EU}:$ Commission Decision of 22 October 2010 adjusting the Union-wide quantity of allowances to be issued under the Union Scheme for 2013 and repealing Decision 2010/384/EU, OJ L 279, 23.10.2010, 3-35. See also Commission Regulation (EU) No $1193 / 2011$ of 18 November 2011 establishing a Union Registry for the trading period commencing on 1 January 2013, and subsequent trading periods, of the Union emissions trading scheme, $O J L 315,29.11 .2011$, p. 1-54. It was also the case for non-ETS sectors: the latest: Commission Decision (EU) 2017/1471 of 10 August 2017 amending Decision 2013/162/EU to revise Member States' annual emission allocations for the period from 2017 to 2020, OJ L 209, 12.8.2017, 53-55.

57 Regulation (EU) No 1315/2013 of the European Parliament and of the Council of 11 December 2013 on Union guidelines for the development of the trans-European transport network and repealing Decision No 661/2010/EU, OJ L 348, 20.12.2013, p. 1-128, recital 33.

${ }^{58}$ Decision No 1313/2013/EU of the European Parliament and of the Council of 17 December 2013 on a Union Civil Protection Mechanism, OJ L 347, 20.12.2013, 924-947, recital 1.

${ }^{59}$ Directive 2008/56/EC of the European Parliament and of the Council of 17 June 2008 establishing a framework for community action in the field of marine environmental policy, OJ L 164, 25.6.2008, 19-40, recital 34. See also Regulation (EU) No 1255/2011 of the European Parliament and of the Council of 30 November 2011 establishing a Programme to support the further development of an Integrated Maritime Policy, OJ L 321, 5.12.2011, 1-10, article 3 (e).

${ }^{60}$ Directive 2012/27/EU of the European Parliament and of the Council of 25 October 2012 on energy efficiency, amending Directives 2009/125/EC and 2010/30/EU and repealing Directives 2004/8/EC and 2006/32/EC, OJ L 315, 14.11.2012, 1-56, recital 1.

${ }^{61}$ Regulation (EU) 2018/1999 of the European Parliament and of the Council of 11 December 2018 on the Governance of the Energy Union and Climate Action, OJ L 328, 21.12.2018, p. 1-77.

62 The determination of this "cap" took place in three successive stages: an experimentation phase from 1 January 2005 to 31 December 2007; a phase corresponding to the first commitment period of the Kyoto Protocol (2008-2012); the current phase which began in 2013 and will end in 2020

${ }^{63}$ Each allowance gives the holder the right to emit one tonne of carbon dioxide $\left(\mathrm{CO}_{2}\right)$, the main greenhouse gas, or the equivalent amount of two more powerful greenhouse gases, nitrous oxide $\left(\mathrm{N}_{2} \mathrm{O}\right)$ and perfluorocarbons (PFCs).

${ }^{64}$ Annex I of the ETS directive sets out five types of activities that produce significant amount of CO2 : (1) energy activities (3 types of facilities are subject to the system: combustion installations with a rated thermal input exceeding $20 \mathrm{MW}$ (except hazardous or municipal waste installations)); mineral oil refineries and coke ovens), (2) production and processing of ferrous metals, (3) the mineral industry, (4) the production of pulp from timber or other fibrous and (5) the production of paper and board for plants with a production capacity exceeding 20 tonnes per day. 
automatic reduction of emissions, without the intervention of public authorities. In reality, reliance on the market has required, in many places, the intervention of public authorities, at the national or EU level, specifically in order to allow the market to function. ${ }^{65}$ The intervention of public authorities, or the "management" of the market, has in fact clearly increased $^{66}$, as the functioning of the market turned out to be defective ${ }^{67}$

Another original feature is the Governance of the Energy Union and Climate Action. Because Member states enjoy considerable autonomy to determine their own energy mix, EU chose a specific governance approach : a flexible one. In its conclusions of 23 and 24 October 2014, the European Council agreed on the 2030 climate and energy policy framework for the European Union explained that "a reliable and transparent governance mechanism with sufficient flexibility for Member States should be developed to help ensure that the Union meets its energy policy goals, while fully respecting Member States' freedom to determine their energy mix"68. To this end, Regulation (EU) 2018/1999 on the Governance of the Energy Union and Climate Action provides that each Member State shall establish an "integrated national energy and climate plan". ${ }^{69}$ From 2021 on, member states will be required to submit biennial progress reports on the implementation of their national plans. The reports would allow the Commission to identify any gap in delivery and take measures to fill those gaps. But, in the same time, this regulation provides that each Member State could take into account any relevant circumstances such as economic conditions and potential, including GDP per capita, potential for cost-effective renewable energy deployment geographical or environmental and natural constraints, including those of non-interconnected areas and regions. ${ }^{70}$ Besides, if the Commission shall assess the plans and their implementation, there are no binding national targets formulated to achieve the European targets and so the reference framework for the Commission to evaluate the ambition of each Member State remains unclear. Furthermore, if the Commission can issue recommendations to Member States, these recommendations won't be binding. Member States should only take due account of them and explain in subsequent progress reports how they have done so. Thus, the effectiveness of this governance depends almost entirely on the goodwill of the member states, although the transparency provided by the national plans and the monitoring and reporting process could open the door for 'naming and shaming' type processes. Having reviewed the new regulation, some would consider the new energy governance regulation as a "harder" form of soft governance ${ }^{71}$

\subsection{Objectives : ambition of its objectives and acceptability of its mechanisms}

The EU climate policy seeks to combine two requirements that must necessarily go hand in hand: ambition of its objectives (and of its results) and acceptability of its mechanisms. Such

\footnotetext{
${ }^{65}$ During the first two phases, it was up to Member States to decide the overall amount of allowances to allocate as well as the way to achieve such allocation as between the facilities targeted at the national level. These choices were to be set out in the National Allocation Plans (NAP)/ However, given the over-allocation of allowances, the quantity of allowances is now set for the whole Union every year since 2013 and this amount shall decrease in a linear fashion by $1.74 \%$ (compared to the average annual amount of allowances issued by Member States for the 2008-2012 period) and then by $2.2 \%$ starting from 2021 .

${ }^{66}$ As a long-term solution, a market stability reserve has been established under Decision (EU) 2015/1814 of the European Parliament and of the Council of 6 October 2015 concerning the establishment and operation of a market stability reserve for the Union greenhouse gas emission trading scheme and amending Directive 2003/87/EC, OJ L 264, 9.10.2015, 1-5.

${ }^{67}$ See on this matter: S. Kingston et al. (2017) o.c. 293.

${ }^{68} \mathrm{Pt}$ 6, European Council (23 and 24 October 2014), Conclusions on 2030 Climate and Energy Policy Framework.

${ }^{69}$ These plans (covering a first period from 2021 to 2030) should pay particular attention to the Member States' binding national targets for greenhouse gas emissions, the annual binding national limits pursuant to Regulation (EU) 2018/842 on binding annual greenhouse gas emission reductions and the indicative national energy contribution to achieving the Union's energy efficiency targets of at least $32,5 \%$ in 2030.

${ }^{70}$ Art. 5-1, Regulation 2018/1999

${ }^{71}$ M. Ringel and M. Knodt, The governance of the European Energy Union : Efficiency, effectiveness and acceptance of the Winter Package 2016, Energy Policy, Volume 112, January 2018, p. 209-220.
} 
a balance between ambition $\left(1^{\circ}\right)$ and acceptability $\left(2^{\circ}\right)$ is complex and necessarily raises the question of the effectiveness of EU policy $\left(3^{\circ}\right)$.

\section{$1^{\circ}$ - Ambition of its objectives}

Although the EU's leadership in international negotiations has clearly fluctuated, the Union has always presented an exemplary level of ambition, both in terms of timing and of scope. ${ }^{72}$ The current objective seeks a reduction by at least $40 \%{ }^{73}$ before 2030 , compared to $1990 \mathrm{~s}$ levels. ${ }^{74}$ To achieve the $40 \%$ minimum target, ETS sectors would have to cut emissions by $43 \%$ (relative to 2005), and non-ETS sectors by $30 \%$ (relative to 2005). There is also targets for reduction in energy efficiency. ${ }^{75}$ In November 2018, the Commission published a communication on its vision for a Long Term Strategy (LTS) on low emissions with a higher ambition : a carbon-neutral society by 2050 .

Furthermore, for each of these targets, the EU has put in place a corresponding set of measures seeking to ensure the achievement of said level. The pursuit of an exemplary policy explains for example the expansion of the scope of the ETS directive in order to include ${ }^{76}$, from 1 January 2012, all flights arriving at or departing from an aerodrome situated in the territory of a Member State. ${ }^{77}$ It also explains why the EU decided to impose obligations on non-ETS sectors, thus reaching beyond facilities covered by the ETS directive, to reduce greenhouse gas emissions by around $10 \%$ in total EU emissions before $2020^{78}$ and by $30 \%$ before 2030 , compared with 2005 levels ${ }^{79}$. Finally, it should be noted that until very recently, land use, land use change and forestry (LULUCF) were excluded from the EU climate and energy package, but a regulation on the inclusion of this sector was adopted on 14 May $2018^{80}$.

The pursuit of exemplariness does not stem solely from the EU's desire to be a global player on this issue. Climate change is also a serious concern for Europe and Europeans. ${ }^{81}$ In fact, “(...) EU's climate change policy (..) offers a chance for European citizens to find out what Europe can do, and to show the wider world what Europe can offer. An ambitious common climate change policy clearly increases the EU's legitimacy domestically". 82

\section{$2^{\circ}$ - Acceptability of its mechanisms}

However, the specificity of the EU's internal policy lies in the fact that ambition had to be combined, every step of the way, with the pursuit of acceptability of the EU's policy by Member States. Indeed, as between Member States, economic contexts vary, positions on climate change differ and energy options can be quite diverse. Furthermore, discrepancies

\footnotetext{
${ }^{72}$ Communication from the Commission to the Council, the European Parliament, the European Economic and Social Committee and the Committee of the Regions, Limiting global climate change to 2 degrees Celsius - The way ahead for 2020 and beyond, COM/2007/0002 final.

${ }^{73}$ In November 2018, the Commission has proposed that the EU reduce its greenhouse gas emissions by $80 \%$ before 2050 , compared to 1990 levels : aforementioned Communication from the Commission, A Clean Planet for all A European strategic long-term vision for a prosperous, modern, competitive and climate neutral economy.

${ }^{74}$ Communication from the Commission to the Council and the European Parliament, The Paris Protocol-A blueprint for tackling global climate change beyond 2020, COM/2015/081 final.

${ }^{75}$ Aforementioned Directive 2012/27/EU which has set the Union-level target for improvements in energy efficiency in 2030 to at least $32,5 \%$.

${ }^{76}$ Directive 2008/101/EC of the European Parliament and of the Council of 19 November 2008 amending Directive 2003/87/EC so as to include aviation activities in the scheme for greenhouse gas emission allowance trading within the Community, OJ L 8, 13.1.2009, 3-21.

${ }^{77}$ However, to support the development of a global measure by the International Civil Aviation Organization (ICAO), the EU has decided to limit the scope of the EU ETS to intra-EEA flights for a period of time. Regulation (EU) 2017/2392 of the European Parliament and of the Council of 13 December 2017 amending Directive 2003/87/EC to continue current limitations of scope for aviation activities and to prepare to implement a global market-based measure from 2021, OJ L 350, 29.12.2017, 7-14.

${ }^{78}$ Aforementioned Decision 406/2009/EC, then aforementioned Regulation (EU) 2018/842.

${ }^{79}$ Aforementioned Regulation (EU) 2018/842, art. 1

${ }^{80}$ LULUCF is included on the basis of "no debit", which means that each Member State has to ensure that emissions from land use are compensated by a removal of $\mathrm{CO}_{2}$ from the atmosphere through action in the LULUCF sector.

${ }^{81}$ According to the Eurobarometer report on climate change, published in September 2017, around three-quarters of European Union (EU) citizens $(74 \%)$ consider climate change to be a very serious problem and more than nine in ten (92\%) see it as a serious problem

${ }^{82}$ R.K.W. Wurzel, Connelly (2010) o.c. 9.
} 
have increased with the enlargements that have taken place throughout the construction of the EU's climate policy. These differences have led to difficulties in agreeing on the European position to uphold in international negotiations and to opposition when adopting internal measures. For example, the Governance regulation was the result of a political struggle between member states such as the UK and Eastern European countries in favour of more flexibility for member states to achieve the energy and climate goals, and other member states that arguing for binding national-level targets for 2030 such as Germany, France, Italy and the Scandinavian countries.

The pursuit of acceptability also explained the negotiation of differentiation legal mechanisms. Visible in the context of the ETS directive ${ }^{83}$, these differentiations appear even more clearly in the instruments adopted for non-ETS sectors. The very title of the first one (the 2009 Effort Sharing Decision ${ }^{84}$ ) testifies to this. In the decision, the emission reduction targets that must be reached by each Member State vary significantly from one State to the other, counterbalanced, however, by a number of flexibility features. ${ }^{85}$ In the new regulation, "the methodology to set the national reduction targets for the non-ETS sectors, with all the elements applied in aforementioned Decision No 406/2009/EC of the European Parliament and of the Council, should be continued until 2030 with efforts distributed on the basis of relative Gross Domestic Product (GDP) per capita" ${ }^{86}$ This methodology is also applied in other matters, for example for the promotion of renewable energies. ${ }^{87}$

\section{$3^{\circ}$ - The issue of the effectiveness of EU policy}

The indicators are rather positive with regard to the achievement of the emission reduction goals for 2020: ${ }^{88}$ compared to 1990 , the decrease of EU emissions is about $22 \%$. Thus, the EU has already surpassed its target of a reduction by $20 \%$ that was set for 2020 .

The EU's target for 2030, a reduction of GHG emissions by at least 40\% compared with 1990 levels, means that this downward trend should be maintained and even reinforced. "However, EU emissions have been increasing since 2014 (on average 1 percent/year), reversing the long-term trend". ${ }^{89}$ The EU itself "recognizes that it is not on track to meet its 2030 target with current policies and has adopted a large package of measures aimed at accelerating the reduction of GHG emissions in different areas". ${ }^{90}$ Only if the measures adopted by the EU in 2018 are fully implemented could a reduction of the Union's emissions by around $45 \%$ occur between now and 2030. It should also be mentioned that the EU set its 2030 objectives based on a $2^{\circ} \mathrm{C}$ temperature rise limit, which is not fully in line with the Paris agreement. A claim has in fact been brought to the Court of First Instance precisely on the basis that the targets authorise emissions in quantities that significantly exceed the objective set by the Paris Agreement of a maximum increase in global average temperature well below $2{ }^{\circ} \mathrm{C}$, keeping in

\footnotetext{
${ }^{83}$ For example, pursuant to the third phase and as part of the gradual move away from the free allocation of allowances towards the auctioning of such allowances, an allocation as between Member States is carried out based on their share of emissions and their economic position: $88 \%$ of the allowances to be auctioned will be distributed among Member States on the basis of their share of verified emissions from EU ETS installations in $2005.10 \%$ will be distributed only to the least wealthy Member States as an additional source of revenue to help them invest in reducing the carbon intensity of their economies and adapting to climate change. The remaining $2 \%$ will be distributed as a 'Kyoto bonus' to Member States which by 2005 had reduced their greenhouse gas emissions by at least $20 \%$ relative to the levels in their Kyoto Protocol base year.

${ }^{84}$ Aforementioned Decision ${ }^{\circ} 406 / 2009 / \mathrm{EC}$

${ }^{85}$ The first mechanism is internal, specific to each Member State: if, in a given year during the 2013-2020 period, it produces more emissions than the authorised figure, a State may carry forward from the following year up to 5\% of its annual emissions allowance (article 3-3). This first mechanism is supplemented by a mechanism relating to interstate trade which allows a Member State to "transfer up to $5 \%$ of its annual emission allocation for a given year to other Member States (...)" (article 3-4), provided that it meets the requirements of the decision.

${ }^{86}$ Recital 2, aforementioned Regulation (EU) 2018/842.

${ }^{87}$ The 2009/28/EC Renewable Energy Directive similarly sets out specific objectives for each Member State with the overall aim of making renewable energy sources account for $20 \%$ of EU energy by 2020 . National reduction objectives set out in Annex I of the directive go from $10 \%$ for Malta to $49 \%$ for Sweden or $23 \%$ for France.

${ }^{88}$ Report from the Commission to the Council and the European Parliament, the Paris Climate Agreement: Taking stock of progress at Katowice COP, COM/2018/716 final.

${ }^{89}$ UNEP (2018) o.c. 14.

${ }^{90}$ UNEP (2018) 13.
} 
mind a more ambitious target of $1.5^{\circ} \mathrm{C} .{ }^{91}$ The applicants request the Court to annul some recents climate acts ${ }^{92}$ and to order the defendants - the Council and the Parliament - to adopt measures leading to a reduction in greenhouse gas emissions by 2030 by $50-60 \%$ of 1990 levels, or even more.

\section{Conclusion}

The pressure on the EU intensified in 2018 at COP 24 after the publication of the IPCC report on the consequences of an increase higher than $1.5^{\circ} \mathrm{C}$. However, it is difficult to see how real progress can be made as long as the EU climate and energy policy is mainly reliant on a 'bottom-up' approach, dependent on the actions and policies of individual member states, over which the Commission has little control. "Governance of the Energy Union will, from 2020 on, be based on the 'building blocks' of national climate, renewable and energy efficiency programmes (...) in the hope that they can be used to construct a Lego-like Energy Union out of separate elements" ${ }^{93}$. Similarly, in the European strategic vision for a climate neutral economy, little explanation is given ${ }^{94}$ about what are the actions planned by the Commission to adopt its mid-century long-term strategy in accordance with the Paris Agreement ${ }^{95}$ nor what is envisaged by the Commission on energy, industry and research \& innovation policies in the framework of the long-term strategy?

\footnotetext{
${ }^{91}$ Action brought on 23 May 2018 - Carvalho and Others $v$ Parliament and Council (Case T-330/18) (2018/C 285/51)

${ }^{92}$ In particular, article 9, paragraph 2, of Directive 2003/87/EC, as last amended by aforementioned Directive 2018/410; article 4(2) of and Annex I to aforementioned Regulation 2018/842 and Article 4 of aforementioned Regulation 2018/841.

${ }^{93}$ M. Keay and D. Buchan, Europe's Energy Union: a problem of governance, Oxford Institute for Energy studies, novembre 2015.

${ }^{94}$ Q. Genard et J. Gaventa, Energy Union governance and the European strategic vision for a climate neutral economy: how will they work together? European Energy Journal (2018) 8(2), 10-14.

${ }_{95}$ The process is however described : According to the governance regulation, EU countries are also required to develop national long-term strategies (LTS) by 1 January 2020, and consistency between long-term-strategies and NECPs has to be ensured. The national LTSs would serve as an input for a joint EU LTS.
} 